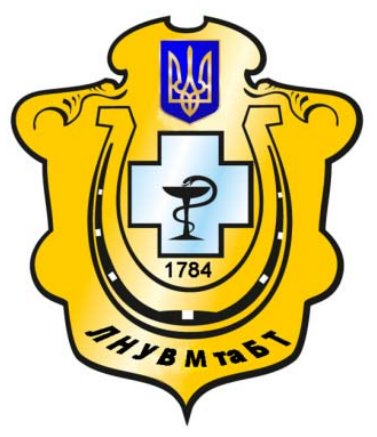

Науковий вісник Львівського національного університету ветеринарної медицини та біотехнологій імені С.3. Гжицького

Scientific Messenger of Lviv National University of Veterinary Medicine and Biotechnologies named after S.Z. Gzhytskyj

doi:10.15421/nvlvet6607

ISSN 2413-5550 print

ISSN 2518-1327 online

$\underline{\text { http://nvlvet.com.ua/ }}$

УДК 619:616.98:579.842.11

\title{
Моніторинг епізоотичної ситуації з колібактеріозу в Україні за період 2004 - 2015 рр.
}

\author{
Т.Б. Васильєва \\ tanya.vasyleva@gmail.com \\ ДНУ «Державний иентр інновачійних біотехнологій», \\ вул. Донецька, 30, м. Київ, 03151, Украӥна
}

Вивчення розповсюдження колібактеріозу в Україні показало на значне його поширення в період з 2004 по 2015 роки. Найбільша кількість неблагополучних пунктів виявлена у Черкаській, Вінницькій, Донецькій, та Тернопільській областях. Проведений аналіз свідчить про збільшення відсотку позитивних зразків біоматеріалу від молодняку ВРХ загинувшого з ознаками колібактеріозу.

Питання розповсюдження колібактеріозу набуває актуальності. Широке використання сучасних антибіотиків унеможливлює виділення чистого ізоляту із патологічного матеріалу. У спектрі інфекиійної патологї с.-г. тварин та птиці найвищий ступінь ураженості спостерігався серед птиці - 3,19\% позитивних результатів від усього дослідженого біоматеріалу, серед свиней - 1,47\%; серед великої рогатої худоби - 0,49\% та інших видів тварин-0,01\%. Колібактеріоз реєструється упродовж року. Найчастіше інфекиія має прояв у період масових отелень.

Молодняк ВРХ хворіс в перші тижні після народження, поросята протягом першого місяия життя. У птиці колібактеріоз має прояв типової секундарної інфекції на фоні зниженого імунітету.

Наявність умов для пасажу патогенних E. coli у тваринницьких господарствах, сприяє розповсюдженню колібактеріозу на всій території краӥни, серед всіх видів сільськогосподарських тварин.

Ключові слова: моніторинг, колібактеріоз, E. coli, телята, поросята, біоматеріал, смертність, інфекиія, неблагополучні пункти, профілактика, гігієна.

\section{Мониторинг эпизоотической ситуации по колибактериозу в Украине за период 2004 - 2015 гг.}

\author{
Т.Б. Васильева \\ tanya.vasyleva@gmail.com
}

ГНУ «Государственный иееттр инновационных биотехнологий»,

ул. Донеикая, 30, г. Киев, 03151, Украина

Изучение распространения колибактериоза в Украине показало на значительное распространение в период с 2004 по 2015 годы. Наибольшее количество неблагополучных пунктов обнаружено в Черкасской, Винничкой, Донеикой и Тернопольской областях. Проведенный анализ свидетельствует об увеличении прочента положительных образиов биоматериала от молодняка КРС погибшего с признаками колибактериоза.

Вопрос распространения колибактериоза приобретает актуальность. Широкое использование современных антибиотиков делает невозможным выделение чистого изолята из патологического материала. В спектре инфекиионной патологии сельскохозяйственных животных и птицы наивысшая степень пораженности наблюдаетяя среди птии - 3,19\% положительных результатов от всего исследованного биоматериала, среди свиней - 1,47\%; среди крупного рогатого скота 0,49\% , других видов-0,01\%. Колибактериоз регистрируется в течение года. Чаще всего инфекция проявляется в период массовых отелов.

Молодняк КРС болеет в первые недели после рождения, поросята в течении первого месяиа жизни. У птии колибакте-

\section{Citation:}

Vasilyeva, T.B. (2016). The monitoring of epizootic situation of colibacteriosis in Ukraine during 2004 - 2015. Scientific Messenger LNUVMBT named after S.Z. Gzhytskyj, 18, 2(66), 30-34. 
риоз имеет проявление типичной секундарной инфекции на фоне сниженного иммунитета.

Наличие условий для пассажа патогенных E. coli в животноводческих хозяйствах способствует распространению колибактериоза на всей территории страны, среди всех видов сельскохозяйственных животных.

Ключевые слова: мониторинг, колибактериоз, E. coli, телята, поросята, биоматериал, смертность, инфекиия, неблагополучные пункты, профилактика, гигиена.

\title{
The monitoring of epizootic situation of colibacteriosis in Ukraine during $2004-2015$
}

\author{
T.B. Vasilyeva \\ tanya.vasyleva@gmail.com
}

SSI «State center of innovation biotechnologies», Donetska Str., 30, Kyiv, 03151, Ukraine

The investigation of colibacteriosis dissemination in Ukraine showed its significant presence during the period 2004-2015. The biggest number of hot spots was detected in Cherkassy, Vinnitsa, Donetsk and Ternopil regions. The data analisys confirmed increasing the persentage level of detected positive samples of biological matherial obtained from young animals died from colibacteriosis.

The problem of colibacteriosis becoming more relevant at the present time. An intensive using of contemporery antibiotics making difficult task of isolating pure microbial culture from pathological matherial. With in the spectrum of infectious diseases of livestock the highest level of infectation was detected among poultry $-3.19 \%$ of positive results from all tested biomatherials from pigs, among pigs $-1.47 \%$, among cattle $-0.49 \%$ and other species $-0.01 \%$. The cases of colibacteriosis was detected during each year. The most common manifestation of infection taking place during calving period.

The young cattle getting disease during first days of life, piglets - during first couple of months. Colibacteriosis in poultry haracterized by typical secondary infection manifestation due to lower immunity.

The conditions for the persistence of pathogenic E.coli in livestock farms provide the possibility for further spreading the infectiong among all kinds of farm animal secies.

Key words: monitoring, colibacillosis, E. coli, calves, piglets, biomaterial, mortality, infection, hot spots, prevention, hygiene.

\section{Вступ}

Грунтовне знання епізоотичної ситуації є запорукою ефективної боротьби і профілактики з інфекційними захворюваннями. Незважаючи на широке використання найсучасніших антибіотиків та біопрепаратів, колібактеріоз, який спричиняють токсигенні Escherichia coli, є лідером за кількістю випадків захворювання та смертності серед інших інфекційних патологій сільськогосподарських тварин (Zaviryukha et al., 1994; Levchenko et al., 1997; Holovko and Ushkalov, 2004; Verbyts'kyy and Holovko, A. (2005).

Колібактеріоз новонароджених телят $є$ найбільш поширеним захворюванням, яке реєструється за останній період у значній кількості господарств різних регіонів України. Слід зазначити, що одним із основних факторів, що впливають на показники захворюваності телят, $є$ низька якість молозива, що пов'язано із рівнем годівлі тільних корів і нетелів (Mel'nychuk et al., 2002; Kuns'ka, 2005).

Відомо, що порушення функції травлення створює передумови для розвитку колібактеріозу через пасажування E. coli на сприйнятливих тваринах і підвищення рівня іiі вірулентності. При цьому, як наголошують науковці, спостерігається зростання кількісного вмісту бактерій $E$. coli у тонкому кишечнику та через адгезивні властивості збудника на епітелії слизової оболонки тонкого кишечнику накопичується товстий шар клітин E. coli, внаслідок чого порушується секреторна функція кишківника (Busol et al., 1995; Vishchur et al., 2015; Setdekov, 2015).

Мета и завдання дослідження. Метою досліджень було провести моніторинг епізоотичної ситуації щодо колібактеріозу в Україні за період з 2004 - 2015 рр. На підставі отриманих даних підтвердити актуальність проблеми для тваринництва України. Встановити видову враженість колібактеріозом та напрямки подолання проблеми.

\section{Матеріал і методи досліджень}

Епізоотологічні дослідження проводили користуючись матеріалами статистичної звітності Державного науково-дослідного інституту з лабораторної діагностики та ветеринарно-санітарної експертизи.

\section{Результати та їх обговорення}

Використовуючи дані офіційної статистики, нами проведений аналіз епізоотичної ситуації з колібактеріозу у господарствах України за останні 12 років упродовж періоду з 2004 по 2015 рр., який показав, що за цей час в Україні було 982 неблагополучних пунктів щодо колібактеріозу. За цей період було доставлено 210418 зразок біоматеріалу від хворих тварин та птиці для бактеріологічних досліджень на колібактеріоз (табл. 1).

Як представлено в таблиці 1, найскладнішою ситуація була у господарствах Черкаського регіону, оскільки за дослідний період було виявлено 596 неблагополучних щодо колібактеріозу пунктів, що складали 57,75\% від усіх неблагополучних на території України. Досить напруженою була епізоотична ситуація щодо колібактеріозу і у інших областях. 
Табличя 1

Епізоотична ситуація щодо колібактеріозу у господарствах України упродовж 2004-2015 pp.

\begin{tabular}{|c|c|c|c|c|c|c|c|c|}
\hline \multirow[b]{2}{*}{ Область } & \multicolumn{2}{|c|}{$\begin{array}{c}\text { Неблагополучних } \\
\text { пунктів }\end{array}$} & \multicolumn{6}{|c|}{ Хворих тварин і птиці } \\
\hline & всього & $\begin{array}{l}\text { \% від загаль- } \\
\text { ної кількості }\end{array}$ & всього & $\begin{array}{l}\text { велика } \\
\text { рогата } \\
\text { худоба }\end{array}$ & $\begin{array}{l}\text { дрібна рога- } \\
\text { та худоба }\end{array}$ & свині & птиця & інші види \\
\hline АРКрим & 18 & 1,74 & 60155 & 122 & 0 & 17 & 16 & 60000 \\
\hline Вінницька & 120 & 11,63 & 5114 & 501 & 17 & 1588 & 2960 & 48 \\
\hline Волинська & 1 & 0,10 & 37 & 5 & 1 & 6 & 20 & 5 \\
\hline Дніпропетровська & 5 & 0,48 & 49 & - & 3 & 15 & 30 & 1 \\
\hline Донецька & 74 & 7,17 & 85241 & 298 & - & 4062 & 80881 & - \\
\hline Житомирська & 2 & 0,19 & 64 & 16 & - & 2 & 46 & - \\
\hline Закарпатська & 1 & 0,10 & 6 & 3 & - & - & - & 3 \\
\hline Запорізька & 5 & 0,48 & 416 & 28 & 2 & 249 & 135 & 2 \\
\hline Івано-Франківська & 6 & 0,58 & 1385 & 42 & - & 7 & 1333 & 3 \\
\hline Київська & 2 & 0,19 & 4 & 2 & - & - & 2 & - \\
\hline Кіровоградська & 5 & 0,48 & 68 & 12 & 1 & 51 & 4 & - \\
\hline Луганська & 8 & 0,78 & 180 & 13 & 5 & 34 & 113 & 15 \\
\hline Львівська & 34 & 3,29 & 2412 & 5 & 1 & 107 & 2299 & - \\
\hline Миколаївська & 9 & 0,87 & 42639 & - & 1 & 607 & 42026 & 5 \\
\hline Одеська & 1 & 0,10 & 793 & 2 & - & 4 & 785 & 2 \\
\hline Полтавська & 6 & 0,58 & 3799 & 19 & - & 5 & 3773 & 2 \\
\hline Рівненська & 3 & 0,29 & 9 & 4 & 1 & - & 4 & - \\
\hline Сумська & 6 & 0,58 & 78 & 9 & 3 & 22 & 42 & 2 \\
\hline Тернопільська & 58 & 5,62 & 3166 & 66 & - & 377 & 2723 & - \\
\hline Харківська & 5 & 0,48 & 352 & 261 & 3 & 88 & - & - \\
\hline Херсонська & 7 & 0,68 & 87 & 7 & 5 & 35 & 40 & - \\
\hline Хмельницька & 7 & 0,68 & 62 & 14 & - & 5 & 43 & - \\
\hline Черкаська & 596 & 57,75 & 4281 & 280 & 1 & 859 & 3110 & 31 \\
\hline Чернівецька & 1 & 0,10 & 16 & 2 & - & 4 & 10 & - \\
\hline Чернігівська & 2 & 0,19 & 6 & 2 & - & 2 & 1 & 1 \\
\hline Всього: & 1032 & 100,00 & 210419 & 1713 & 44 & 8146 & 140396 & 60120 \\
\hline \multicolumn{3}{|c|}{ \% від загальних показників } & 100,00 & 0,81 & 0,02 & 3,87 & 66,73 & 28,57 \\
\hline
\end{tabular}

Проведений нами моніторинг показав, що серед тваринницьких господарств Вінницької області за дослідний період були відкриті неблагополучні по колібактеріозу пункти, кількість яких складала 11,63\% від їх загальної кількості на території держави; у Донецькій області - 7,17\%; Тернопільській 5,62\% та Львівській - 3,29\% відповідно.

Слід відмітити, що складною була епізоотична ситуація з колібактеріозу в господарствах АР Крим, де утримувались інші види тварин. Зокрема, частка зразків біоматеріалу для бактеріологічних досліджень 3 підозрою на колібактеріоз від інших видів тварин складала 28,57\%. Аналіз епізоотичної ситуації щодо колібактеріозу у господарствах України показав, що захворюваність серед великої рогатої худоби упродовж 2004 - 2015 рр. складала $0,81 \%$ від загальної кількості усіх хворих тварин та птиці. Найбільша ураженість серед великої рогатої худоби спостерігалася у господарствах Вінницької (501 гол.), Донецької (298 гол.), Черкаської (280 гол.) та Харківської (261 гол.) областей та АР Крим (122 гол.), оскільки кількість зразків біоматеріалу від загиблих тварин із ознаками колібактеріозу значно перевищувала показники у тваринницьких господарствах інших регіонів.

Слід відмітити, що у західних та північнозахідних регіонах України ситуація щодо колібактері- озу виявилась значно кращою, оскільки упродовж дослідного періоду у господарствах Рівненської, Чернігівської, Закарпатської областей, а також у Луганській і Сумській областях було зафіксовано відносно невелику кількість хворих тварин.

Як показав аналіз бактеріологічних досліджень (табл. 2), найвища ураженість збудником колібактеріозу була серед птиці, оскільки від цих тварин поступило 71,98\% біоматеріалу від усіх досліджених зразків. Відсоток позитивних результатів склав $61,66 \%$ від загальної кількості досліджених біоматеріалів.

Біоматеріал від свиней складав 20,15\% від загальної кількості, проте лише у 28,44\% випадків був ізольований збудник E. coli. Біоматеріал від великої рогатої худоби складав 7,03 \% від загальної кількості зразків і у 9,56\% випадків був ізольований збудник колібактеріозу. Відсоток біоматеріалу від інших тварин складав $0,84 \%$. Серед них було виявлено позитивних результатів у $0,34 \%$ випадків.

У спектрі інфекційної патології с.-г. тварин та птиці найвищий ступінь ураженості спостерігався серед птиці - 3,19\% позитивних результатів від усього дослідженого біоматеріалу, серед свиней - 1,47\%; серед великої рогатої худоби - 0,49\% та інших видів тварин $-0,01 \%$ (табл. 2). 
Дослідження зразків від тварин і птиці упродовж 2004-2015 pp.

\begin{tabular}{|c|c|c|c|c|c|}
\hline \multirow[b]{2}{*}{$\begin{array}{l}\text { Вид тва- } \\
\text { рин }\end{array}$} & \multicolumn{2}{|c|}{ Досліджено зразків біоматеріалу } & \multicolumn{2}{|c|}{ Отримано позитивних результатів } & \multirow{2}{*}{$\begin{array}{c}\text { \% позитивних } \\
\text { зразків до загаль- } \\
\text { ної кількості дос- } \\
\text { тавленого біома- } \\
\text { теріалу, }\end{array}$} \\
\hline & $\begin{array}{c}\text { кількість зразків } \\
\text { біоматеріалу }\end{array}$ & $\begin{array}{c}\text { \% до загальної кіль- } \\
\text { кості } \\
\text { досліджених зразків }\end{array}$ & $\begin{array}{c}\text { кількість зразків } \\
\text { біоматеріалу }\end{array}$ & $\begin{array}{c}\text { \% до загальної } \\
\text { кількості } \\
\text { досліджених зразків }\end{array}$ & \\
\hline BPX & 25773 & 7,03 & 1817 & 9,56 & 0,49 \\
\hline Свині & 73959 & 20,15 & 5404 & 28,44 & 1,47 \\
\hline Птиця & 264130 & 71,98 & 11717 & 61,66 & 3,19 \\
\hline Інші види & 3088 & 0,84 & 65 & 0,34 & 0,01 \\
\hline Всього & 366950 & 100,0 & 19003 & 100,0 & \\
\hline
\end{tabular}

Дослідження біоматеріалу від ВРХ із господарств упродовж 2004-2015 pp.

Таблиия 3

\begin{tabular}{|c|c|c|c|}
\hline \multirow{2}{*}{ Роки } & \multicolumn{3}{|c|}{ Біоматеріал від тварин, що загинули з ознаками колібактеріозу: } \\
\cline { 2 - 4 } & \multirow{2}{*}{ всього } & одержано позитивних результатів: & \% від досліджених \\
\cline { 2 - 4 } & & 413 & 9,83 \\
\hline 2004 & 4201 & 276 & 8,16 \\
\hline 2005 & 3392 & 258 & 7,15 \\
\hline 2006 & 3605 & 233 & 7,95 \\
\hline 2007 & 2932 & 189 & 2,60 \\
\hline 2008 & 3364 & 35 & 3,54 \\
\hline 2009 & 1172 & 33 & 2,38 \\
\hline 2010 & 932 & 23 & $\mathbf{2 , 3 3}$ \\
\hline 2011 & 963 & $\mathbf{2 4}$ & 3,09 \\
\hline 2012 & $\mathbf{1 0 2 9}$ & 22 & 5,4 \\
\hline 2013 & 710 & 85 & $\mathbf{1 1 , 8}$ \\
\hline 2014 & 1570 & $\mathbf{2 2 6}$ & 7,05 \\
\hline 2015 & $\mathbf{1 9 0 3}$ & 1817 & \\
\hline Всього & 25773 & & \\
\hline
\end{tabular}

За даними табл. 3 встановлено, що за останні роки збільшилися об'єми біоматеріалу з підозрою на колібактеріоз від великої рогатої худоби та зросла кількість підтверджень позитивних випадків захворювання із 2,33\% у 2012 до 11,8\% у 2015 рр., що підтверджує постійну циркуляцію збудника E. coli в господарствах України. Це є підставою для удосконалення профілактичних заходів щодо боротьби з колібактеріозом.

\section{Висновки}

1. Аналіз епізоотичної ситуації свідчить, що колібактеріоз реєструється на всій території України.

2. Встановлено тенденцію до збільшення об'ємів біоматеріалу з підозрою на колібактеріоз, та зростання відсотку позитивних результатів.

Перспективи подальших досліджень. Існуючі засоби специфічної профілактики недостатньо ефективні; це підтверджується тим, що захворюваність і смертність тварин від ешерихіозу залишається на високому рівні і реєструється в більшості господарств України. Головним напрямком боротьби 3 ешерихіозами $є$ активна імунізація. Створення і застосування нових профілактичних засобів забезпечить ефективний захист імунізованих тварин від захворювання.

\section{Бібліографічні посилання}

Holovko, A., Ushkalov, V. (2004). Epizootolohichnyy monitorynh. Esherykhioz (kolibakterioz) tvaryn [Epi- zootological monitoring. colibacillosis animals]. Veterynarna medytsyna Ukrayiny. - Veterinary Medicine Ukraine, 2, 6- 9 (in Ukrainian).

Levchenko, V.I., Zayarnyuk, P.I., Papchenko, V.V. (1997) Shlunkovo-kyshkovi khvoroby novonarodzhenykh telyat [Gastrointestinal disease of the newborn calves]. Bila Tserkva (in Ukrainian).

Zaviryukha, A.I., Levchenko, V.I., Fuks, P.P. (1994). Systema veterynarnykh zakhodiv po vyroshchuvannyu zdorovykh telyat. [The system of veterinary measures for growing healthy calves]. Zberezhenist' molodnyaka s.-h. tvaryn - zaporuka rozvytku tvarynnytstva Ukrayiny: Zb. statey nauk.-prakt. Konferentsiyi. Kharkiv, 5-6 (in Ukrainian).

Verbyts'kyy, P., Holovko, A. (2005). Rol' vaktsynatsiyi tvaryn u systemi protyepizootychnykh zakhodiv. [The role of the immunization system in animal disease control measures] Veterynarna medytsyna Ukrayiny. 9, 10-12 (in Ukrainian).

Kuns'ka, K.M. (2005). Vplyv struktury ratsioniv koriv na molochnu produktyvnist' ta zberezhenist' telyat. [The impact of dietary patterns on cow milk production and calf survival]. Visnyk Bilotserkivs'koho derzhavnoho ahrarnoho universytetu. Bila Tserkva, 33, 116 - 121 (in Ukrainian).

Mel'nychuk, D.O., Tsvilikhovs'kyy, M.I., Hryshchenko, V.A. (2002). Zakonomirnosti formuvannya kolostral'noho imunitetu u novonarodzhenykh telyat. Ukrayins'kyy biokhimichnyy zhurnal. 74(2), 21-25 (in Ukrainian). 
Vishchur, O.I., Gutyj, B.V., Hufriy, D.F., Khariv, I.I., Solovodzins'ka, I.Ye. (2015). Imunnyy status, sposoby otsinky i metody korektsiyi u telyat rann'oho viku [Immune status, methods of evaluation and correction methods calves early age]: monohrafiya. L'viv: SPOLOM (in Ukrainian).

Busol, V.O., Fuks, P.P., Konarzhevs'kyy, K.Ye. (1995). Mikroflora kyshechnyka dorosloyi velykoyi rohatoyi khudoby i zdorovykh ta khvorykh na kyshkovi khvoroby novonarodzhenykh telyat [Adult gut of cattle and healthy and patients with gastrointestinal dis- eases of newborn calves]. Veterynarna medytsyna K.: Urozhay. 70, 63 (in Ukrainian).

Setdekov, R.A. (2015). Izuchenie profilakticheskoy effektivnosti sub'edinichnoy protivokolibakterioznoy vaktsinyi $\mathrm{v}$ neblagopoluchnom po esherihiozu telyat hozyaystve. Uchenyie zapiski Kazanskoy gosudarstvennoy akademii veterinarnoy meditsinyi im. N.E. Baumana. 221, 201-204 (in Russian).

Стаття надійшла до редакиії 23.09.2016 